\title{
SOLITARY FIBROUS TUMOR OF ADRENAL GLAND AND REVIEW OF THE LITERATURE
}

\author{
Martina Ambardjieva ${ }^{1}$, Skender Saidi ${ }^{1}$, Rubens Jovanovic ${ }^{2}$, \\ Josif Janculev ${ }^{1}$, Viktor Stankov ${ }^{1}$, Aleksandar Trifunovski ${ }^{1}$, Zivko Popov ${ }^{3}$ \\ ${ }^{1}$ University clinic for urology, Faculty of medicine, Ss. Cyril and Methodius University in Skopje, R. N. Macedonia \\ ${ }^{2}$ Institute of Pathology, Faculty of medicine, Ss. Cyril and Methodius University in Skopje, R. N. Macedonia \\ ${ }^{3}$ Macedonian Academy of Sciences and Arts, Skopje, R. N. Macedonia
}

Corresponding author: Martina Ambardjieva MD, University clinic for urology, Vodnjanska 17, 1000 Skopje, Republic of North Macedonia. Tel: +389-78-403122, E-mail: martina.ambardzieva@gmail.com

\begin{abstract}
Solitary fibrous tumor (SFT) is a rare and still controversial entity. This type of tumor first appeared in the literature as a pleural lesion, but, over the last decades, it has been reported in many extrathoracic sites. As a tumor of the adrenal gland, SFT is still rare and very uncommon, thus extensive research among the English language literature has been performed. We present here a case report of an adrenal SFT which is compared to 11 other known cases. Our case report is from a patient with SFT on the left adrenal gland, followed by mild symptoms of abdominal discomfort and hypertension. Physical examination, laboratory, and radiological tests were performed. The patient underwent surgery and the material was sent for histopathologic analysis for a definite diagnosis. Regular follow up appointments were performed over the course of two years. No recurrence of the tumor has been detected.

We explain the symptoms, diagnosis, treatment, and additionally we describe the results and implications of the findings reported in the literature. Correct diagnosis is mandatory for optimal management of solitary fibrous tumor patients.
\end{abstract}

Keywords: solitary fibrous tumor, adrenal gland, adrenalectomy

\section{INTRODUCTION}

Solitary fibrous tumors (SFT) usually originate from the pleura [1] and rarely occur in the retroperitoneum, especially the adrenal area. SFT are rare, well-circumscribed, and grey-white to yellow-white in color. Microscopically, they are hypercellular or hypocellular with a "patternless pattern". They also contain staghorn shaped vessels. Solitary fibrous tumors are not the same as hemangiopericytoma, but because their major histological characteristics overlap, pathologists have been gradually abandoning the term heman- giopericytoma and using the term solitary fibrous tumor [2].

Usually, this type of tumor is painless, except in certain cases where pain is associated with compression with other tissues.

Extensive review of the English language literature was used to identify all previously reported cases of SFT of the suprarenal gland. To the best of our knowledge there are twelve (12) 
cases in the literature of solitary fibrous tumors that emerge from the adrenal lodge.

The aim of this article is to present this rare case and review 11 similar cases reported in the English language literature over the last 25 years.

\section{CASE REPORT}

A 28 year old man was admitted to the urology clinic with a history of mild left abdominal and back pain. Physical examination showed no abnormal findings except for mild abdominal discomfort at palpation. He had a history of hypertension (160-100 $\mathrm{mmHg}$ ), and pulse, oxygen saturation, and body temperature were 71 beats $/ \mathrm{min}$, $98 \%$, and $36.5{ }^{\circ} \mathrm{C}$, respectively. His blood work laboratory values were: hemoglobin was $144 \mathrm{~g} / 1$, red blood cell count was $4.1 \times 10^{12} / \mathrm{L}$, white blood cell count was $6.5 \times 10^{9} / 1$, platelets were $310 \times 10^{9} / 1$, creatinine $77 \mu \mathrm{mol} / 1$, sodium was 140,2 mmol/1, potassium was $4,78 \mathrm{mmol} / \mathrm{l}$. Also the values of cortisol at $8 \mathrm{~h}$ was $768.4 \mathrm{nmol} / \mathrm{L}$, cortisol at $16 \mathrm{~h}$ was $837.7 \mathrm{nmol} / \mathrm{L}$, adrenocorticotropic hormone (ACTH) was $41.4 \mathrm{nmol} / \mathrm{L}$ and vanillylmandelic acid (VMA) was $4.6 \mathrm{mg} / 24 \mathrm{~h}$.

Urine examination showed no leukocyturia or bacteriuria. Also, patient's HIV antibody was negative. X-ray examination of kidney, ureter, and bladder was unremarkable. Computed tomography and magnet resonance were performed, and these revealed a well-circumscribed heterogeneous mass measuring $6 \times 6 \times 7 \mathrm{~cm}$, located in the left suprarenal area (Fig. 1). Urine cytology was negative for malignant cells.

The patient underwent surgery. According to a standard operative procedure, ligation of the adrenal vein was performed, and after that, the adrenal gland was released from its surroundings. After removing the adrenal gland, it was observed that the tumor was located outside of the adrenal gland and it had a compression effect on the gland. As a result of this, additional excision was performed and the material was sent for a histopathology analysis.

\section{Histopathologic findings:}

Gross description: The material contains an adrenal gland measuring $7 \times 3 \times 1 \mathrm{~cm}$ and surrounding adipose tissue measuring $11 \times 6 \mathrm{~cm}$ and weighing a total of 140 grams. In the material there is a clearly demarcated tumor node measuring $5.5 \times 5 \mathrm{~cm}$, with gray-brown coloration and a soft consistency on serial sections. The tumor tightly abutted the stretched identifiable adrenal gland (Fig. 2).

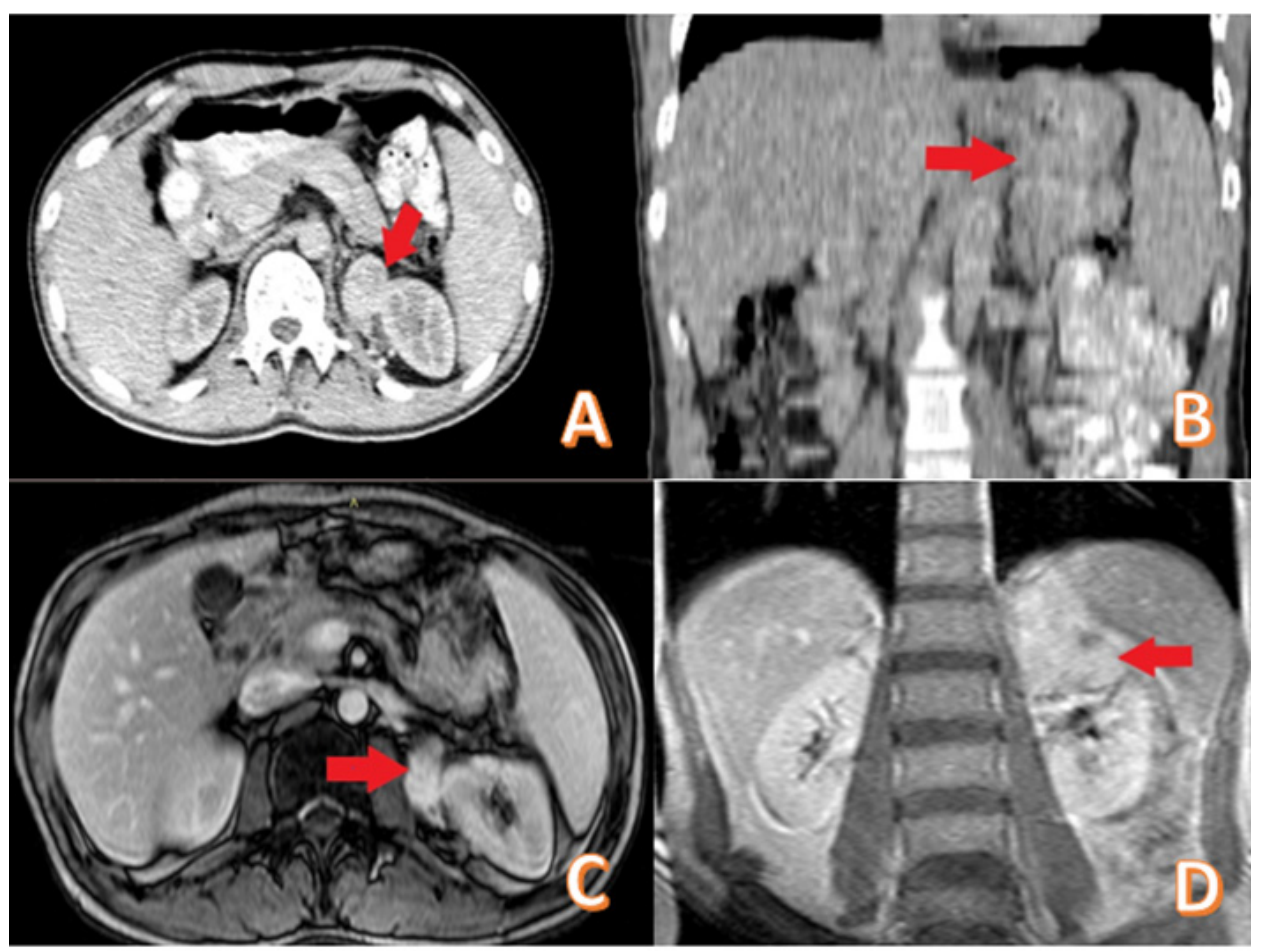

Figure 1. A and B-Computed tomography scan of solitary fibrous tumor of left adrenal gland $\boldsymbol{C}$ and $\boldsymbol{D}$-Magnetic resonance of solitary fibrous tumor of left adrenal gland 


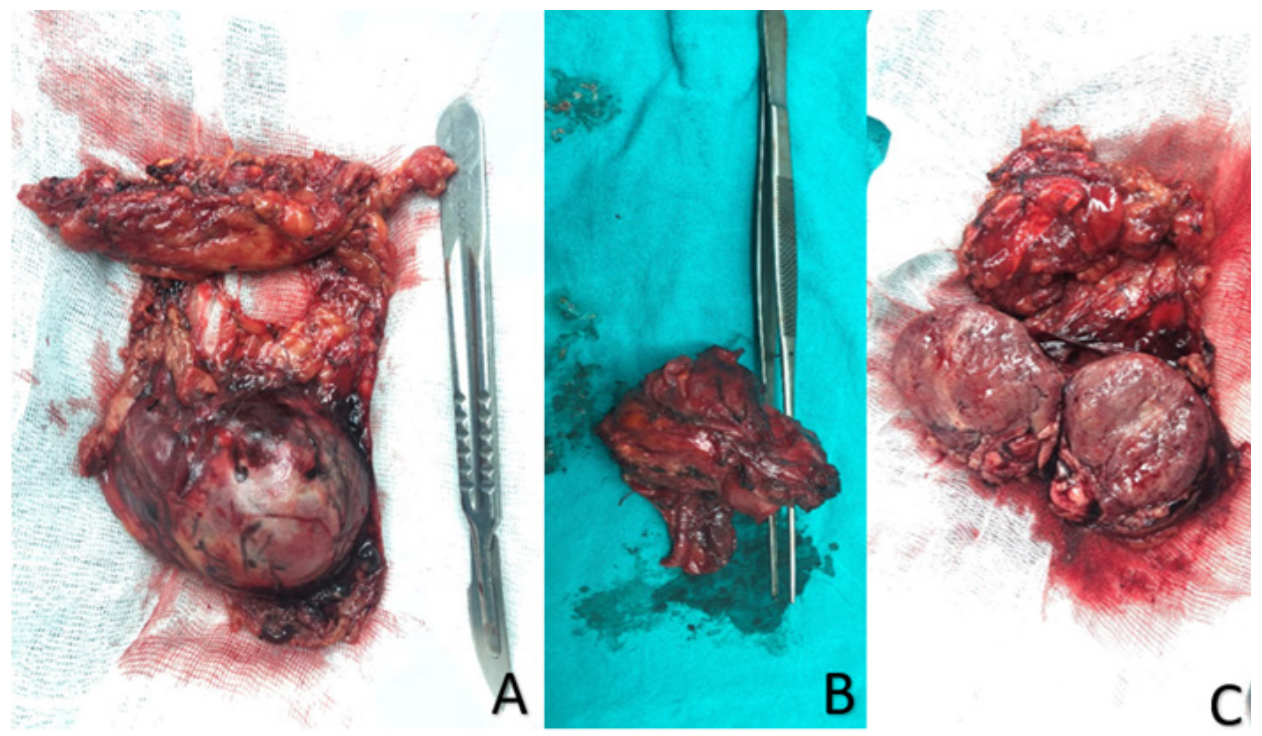

Figure 2. A and B-Resected specimen of solitary fibrous tumor compared to surgical instruments $\boldsymbol{C}$-Macroscopic pathological finding of the specimen

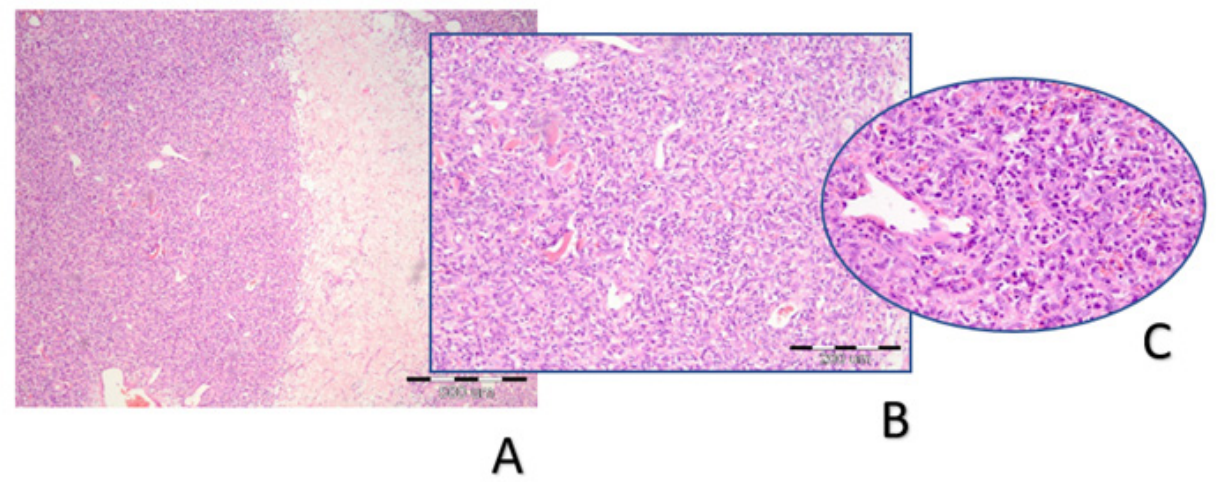

Figure 3: Cells are arranged in bundles of swirly and fascicular arrangement. Rich cellular neoplasm composed of fusiform and oval cells. A. HeEo x 40, B. HeEo x 100 C. HeEo 200 (Spindle-shaped cells with "paternless" distribution)

Microscopic analysis of the described node showed a hypercellular neoplasm composed of fusiform and oval cells with blurred cytoplasmic boundaries containing an elongated or oval nucleus. Some of the nuclei were euchromatic, and some showed a vesicular appearance with an irregular nuclear membrane. Cells were arranged in bundles of swirly and fascicular arrangement. Between them were numerous blood vessels and, in some areas, strips of collagen matrix. Mitotic divisions were rare (Fig. 3). Immunohistochemical analysis showed positive staining for Vimentin and CD34, and staining for S100; Factor VIII; CKAE1 / AE3; S100-a4 were negative. The staining forKi67 showed a low proliferative index (about 5\%) (Fig. 4). Microscopic analysis of adrenal specimens showed normal histo- morphology. Based on the histopathological and immunohistochemical findings, the diagnosis of a solitary fibrous tumor (hemangiopericytoma) was made.

The patient was discharged from the hospital in good condition 3 days after the surgery. Regular follow up appointments were performed over the course of two years. Postoperative ultrasound and laboratory findings were in the reference range 45 days after the surgery. Hormones levels that were elevated before returned to normal levels. Additionally, an abdominal CT scan was performed after 6 months, and an MRI was performed 12 and 24 months after surgery.

No recurrence of the tumor has been detected. 


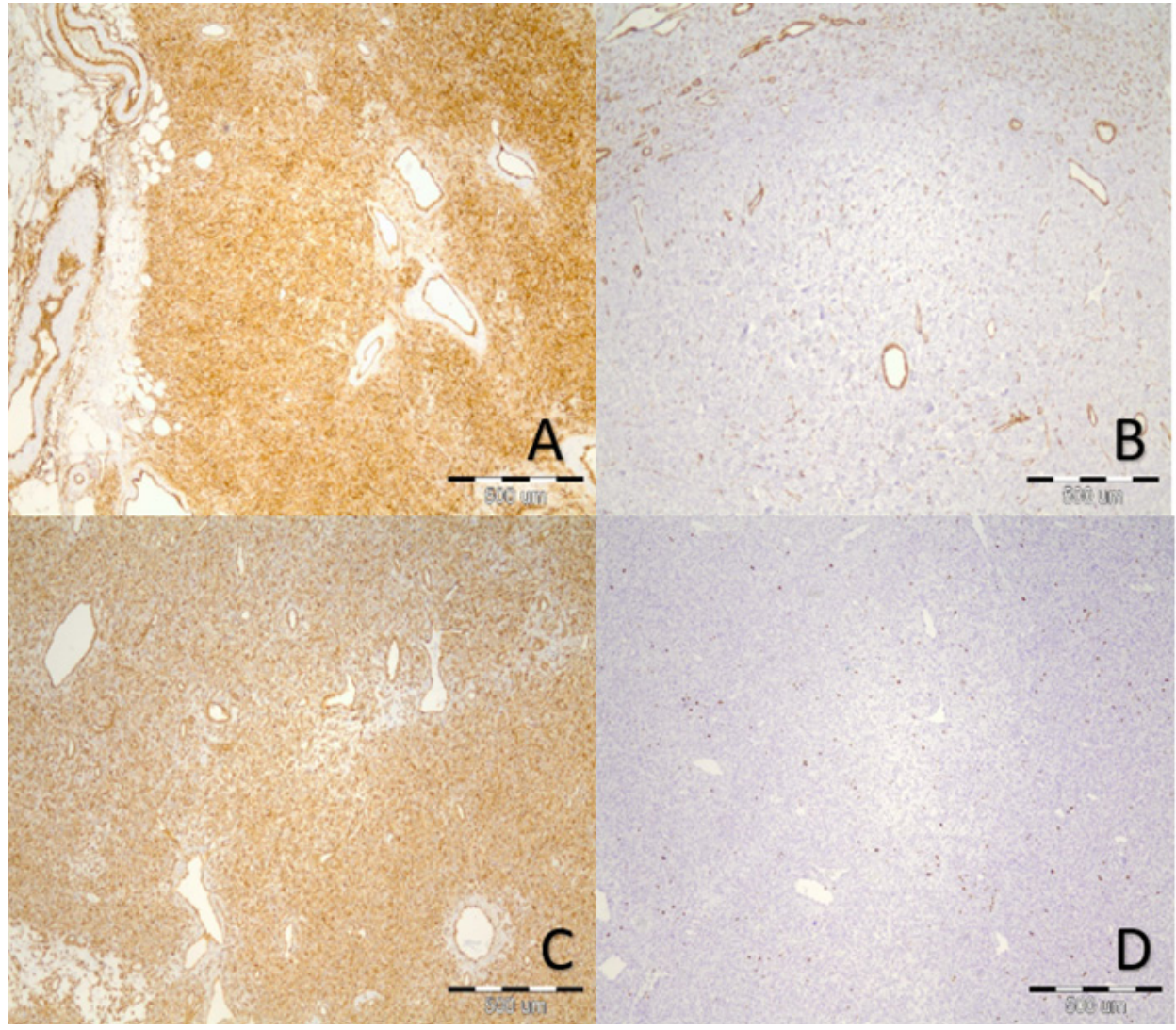

Figure 4. A. Immunohistochemical staining: CD34 positive; $\boldsymbol{B}$.

Immunohistochemical staining: Vimetin positive; $\boldsymbol{C}$. Smooth muscle actin (SMA) was negative; $\boldsymbol{D}$. The proliferation rate Ki67 shows a low proliferative index (about 5\%)

\section{DISCUSION}

SFT is a tumor that was first described as a tumor with pleural origin [1]. Rarely can it be located in the extrathoracic region, for example: kidney [3], urinary bladder [4], scrotum [5], liver, prostate, abdomen [4], oral cavity, nasopharyngeal, the neck [6] and other locations.

This type of tumor between endocrine organs, can be found in the thyroid gland [7], pan- creas [8], pituitary gland [9], but very rarely in the adrenal gland.

In the adrenal gland, a primary occurrence of solitary fibrous tumor had only been documented eleven times in the English literature [10-20] (Table 1).

In our presented case, the patient was male, while in the conducted analyses there have been 6 male cases and 5 female cases.

The patients' ages ranged from 23 to 77 years and the mean age was 47 years. Our report represents the second oldest patient, or the youngest male.

Table 1: 12 case reports with SFT (including our case)

\begin{tabular}{|c|c|c|c|c|c|c|c|c|c|c|c|c|}
\hline \multirow{3}{*}{ Case $\mathrm{No}$. } & \multirow[b]{2}{*}{ Publicatio } & \multirow{2}{*}{ Country } & \multirow{2}{*}{ Author } & \multicolumn{9}{|c|}{$\begin{array}{l}\text { Patieat } \\
\text { Ste }\end{array}$} \\
\hline & & & & Age & Sex & Diagnostic & Lab & T. side & Tumor size & Comorbidity & Ireatmeat & Symptoms \\
\hline & $1906 \mid$ & & s Pretive ef a d & 42 & $w$ & USG & & $\mathbf{R}$ & & & surgery after 5 years & no \\
\hline & 2019 & Jappa & 5. Kurkayashi i al & $\mathrm{C}_{2}$ & $m$ & CT & $\begin{array}{l}\text { I urinary sormetaneflarise } \\
\text { (pheochromocicena) }\end{array}$ & L & $\mid \begin{array}{l}3-10 \mathrm{~cm} \\
\text { (after } 7 \text { years) }\end{array}$ & $\begin{array}{l}\text { pheochremschicenas } \\
\text { pastric Ulet }\end{array}$ & 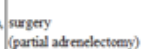 & 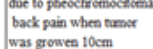 \\
\hline & 2000 & & Bongoverexi M ef al & 23 & $w$ & USG and MR & 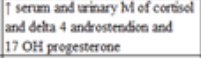 & L & $\begin{array}{l}-6-9 \mathrm{~cm} \\
\text { affer } 3 \text { months }\end{array}$ & 1) pregnancy & surgety (lap) & no \\
\hline & 2019 & Trusisia & Diataga S. et 2 al & 52 & $m$ & USG and CT & & $\mathrm{R}$ & $11 \times 10 \times 9 \mathrm{~cm}$ & & surgery & right humber pain \\
\hline & 2019 & Etbispiz & H. W. Getreselassic et al & 13 & $\mathrm{w}$ & USG and CT & & $\mathrm{R}$ & $18 \times 15 \times 12 \mathrm{~cm}$ & & surgery & $\begin{array}{l}\text { dall dragging pain } \\
\text { and low grade fever }\end{array}$ \\
\hline 6 & 2007. & Sapran & Kathera et al & 39 & $w$ & CT and MRI & mis anemia & L & $10 \mathrm{~cm}$ & & surgery & getereral fatipue \\
\hline 7 & 2010 & Simzepore & Ho et al & 71 & $m$ & USG and CT & & $\mathrm{R}$ & $11.7 \times 8.7 \mathrm{~cm}$ & & surgery & no \\
\hline 8 & 2011 & Kerea & S.B. Park et al & $\infty 6$ & $\mathrm{w}$ & CT and MRI & & $\mathrm{L}$ & & & & fank pin \\
\hline 9 & 20014 & traty & G. Tregha ex al & 33 & $m$ & PETCT & & $\mathrm{R}$ & $2.5 \mathrm{~cm}$ & & sursery & fener \\
\hline 10 & 20013 & thaty & A. Tortiato ef al & 54 & $m$ & USG and MRI & & Bal & $15 \mathrm{~cm} \mathrm{R} \cdot 4 \mathrm{~cm} 1$ & & sursery (tpratait) & severe thpertention \\
\hline 11 & 2021 & & 5. E. Howisman et al & $\pi$ & $m$ & CI & no atboormalties & $\mathrm{R}$ & & & surgery (2ap) & \\
\hline 12 & 2018 & Macedonia & Abardjieva M. ef al & 28 & $\mathrm{~m}$ & CI & & L & $7 \times 3 \times 1 \mathrm{~cm}$ & & & abdominal pain \\
\hline
\end{tabular}


From the research, it can be noted, that in the most of the cases solitary fibrous tumor can be found in isolated form. Only in two cases did this type of tumor occur with other conditions like pregnancy [12] and pheochromocytoma [11].

The tumor cannot be associated with any side occurrence, it was spotted on the left and on the right adrenal gland. Only in one of the cases did it appear as bilateral and a partial adrenalectomy was performed [19]. A partial adrenalectomy was also performed in the Kuribayashi et al. case as a result from previous pheochromocytoma adrenalectomy. In all of the other cases, including our case, full adrenalectomy was performed.

The median diameter of the tumors was $9.85 \mathrm{~cm}$ (range $2.5-18 \mathrm{~cm}$ ), and tumors smaller than $10 \mathrm{~cm}$ were observed in four patients, including our case.

Tumor growth rates vary between cases. In the Bongiovanni case [12], the tumor was detected during casual ultrasonographic pregnancy monitoring and significantly increased in size during the last three months of the pregnancy. In the Kuribayashi et al. case [11], the tumor did not grow rapidly.

In the last decade, these types of tumors have been characterized as asymptomatic tumors [6]. In both the Yonly [13] and Kuribayashi [11] cases when the patient's tumor reached size of $10 \mathrm{~cm}$, pain symptoms were reported and the patients decided to undergo surgery. This clearly shows that tumor related pain symptoms are the main reason for deciding to undergo surgery in this case.

To the best of our knowledge, the tumor presented in our case is the first that has emerged at this location and is associated with pain, even though its size is less than $10 \mathrm{~cm}$. Besides Toniato's case [19], this is the second case in which mild hypertension was reported.
Elevated serum levels of cortisol are observed in our case and also in the case of Bongiovanni [12]. In our opinion, this is due to the compressive effect of the tumor. This explains the decline in elevated hormones after adrenalectomy.

In the literature there is mention about paraneoplastic syndrome with solitary fibrous tumor that is localized in the kidney [3]. In this case, hypoglycemia was reported. In the literature, research, and in our presented case, there are no mentions of paraneoplastic syndrome and solitary fibrous tumor of the adrenal gland.

Although it is not proven that these types of tumors are potentially malignant, there is a need for adequate long-term follow up. This is noted in the study of W.H.Ho [16], where, in view of the size of the tumor and the increased mitotic activity (up to six mitotic figures per ten high power fields), it has labeled the tumor as having an uncertain malignant potential.

Treglia et al. reported on a patient who underwent investigation for fever of an unknown origin and was later found to have an SFT of the adrenal gland [18]. Gebresellassie also reported a fever. In Kakihara's case, the symptoms of general fatigue were reported [15]. In our case, none of these symptoms were reported by the patient.

The most characteristic immunohistochemical finding in SFT is CD34 expression [21]. All literature cases, and our presented case also, have the CD34 expression. 6 of the cases showed a positive signal to bcl2, 3 cases showed a positive signal to vimentin and 3 cases showed a positive signal to STAT6. Only one of the cases showed a positive signal to S100 [16]. This indicates the presence of a malign component of the solitary fibrous tumor (Table 2).

In Rajaeev [22], there is a relapse of disease if the tumor's size is larger than $10 \mathrm{~cm}$. Although it is noted that histological characteris-

Table 2: Microscopic characteristics reported in the twelve cases in the literature

\begin{tabular}{|c|c|c|c|c|c|c|c|c|c|}
\hline \multirow[b]{2}{*}{ Case n. } & \multirow[b]{2}{*}{ lication } & \multirow[b]{2}{*}{ Country } & \multirow[b]{2}{*}{ Author } & \multicolumn{6}{|c|}{ HPA } \\
\hline & & & & $\begin{array}{r}\text { proliferativ } \\
\text { index Ki67 }\end{array}$ & vimetin & bcl2 & CD34 & STAT6 & S-100 \\
\hline 1 & 1996 & & S Prévot et al & & & & positive & & \\
\hline 2 & 2019 & Japan & S. Kuribayashi et al & & & & positive & positive & \\
\hline 3 & 2000 & & Bongiovanni $\mathrm{M}$. et al & $6 \%$ & positive & positive & positive & & \\
\hline 4 & 2019 & Tunisia & Diataga S. et al. & & & & positive & & \\
\hline 5 & 2019 & Ethiopia & H. W. Gebresellassie et al & & & positive & positive & positive & \\
\hline 6 & 2007 & Japan & Kakihara et al. & & & & positive & & \\
\hline 7 & 2010 & Singapore & Ho et al & & & positive & positive & & positive \\
\hline 8 & 2011 & Korea & S.B. Park et al & & & & & & \\
\hline 9 & 2014 & Italy & G. Treglia et al & & & positive & positive & & negative \\
\hline 10 & 2013 & Italy & A. Toniato et al & $10 \%$ & positive & positive & positive & & negative \\
\hline 11 & 2021 & & S. E. Huisman et al & & & positive & positive & positive & \\
\hline 12 & 2018 & Macedonia & Ambardjieva M. et al & $5 \%$ & positive & & positive & & negative \\
\hline
\end{tabular}


tics and the Ki-67 label index are helpful for the diagnosis of a malignant SFT. It is indicated that surgical treatment is primary. In all of the reported cases with adrenal gland tumors, there is no strong mitotic index, even though most of the tumors are larger than $10 \mathrm{~cm}$.

\section{CONCLUSION}

A solitary fibrous tumor shows many benign characteristics. It is often an asymptomatic, incidental finding, but SFT may also be revealed via lumbar pain. From this research we can conclude that if surgical treatment is performed on time, partial adrenalectomy is also possible. Also, lymphadenectomy is not necessary. However, the prognosis of SFT is unpredictable even if there were not atypical histological features, as was the case in our patient, but malignity is not strictly dependent on histologic features alone.

\section{REFERENCES}

1. Klemperer P, Rabin CB. Primary neoplasm of the pleura: a report of 5 cases. Arch Pathol, 11, 1931, 385-412.

2. Sung B. P., Yang S. P., Jeong K. K et al. Solitary Fibrous Tumor of the Genitourinary Tract. American Journal of Roentgenology. 2011; 196: 132-137.

3. Khowaja A., Johnson-Rabbett B., Bantle J.et al., Hypoglycemia mediated by paraneoplastic production of Insulin like growth factor-2 from a malignant renal solitary fibrous tumor - clinical case and literature review. BMC Endocrine Disorders. 2014; 14: 49.

4. Sun S., Tang M., Dong H., Liang C. et al. Solitary fibrous tumor involving urinary bladder: a case report and literature review. TranslAndrolUrol 2020; 9(2): 766-775.

5. Chang TH, Chen M and Lee CC. Solitary fibrous tumor of the scrotum: a case report and review of the literature. BMC Urology. 2019; 19: 138.

6. Ceballos M., Hernández A., Cruz-Ortiz $\mathrm{H}$ et al. Solitary fibrous tumor: clinicopathological study of 16 cases. Cirugia y Cirujanos 2011 79(5): 417-23.

7. Ghasemi-Rad M, Wang KY, Jain S et al. Solitary fibrous tumor of thyroid: a case report with review of literature. Clin Imaging. 2019; 53: 105-107.
8. Chetty R, Jain R, Serra S. Solitary fibrous tumor of the pancreas. Ann DiagnPathol. 2009; 13(5): 339-343.

9. Furlanetto TW, Pinheiro CF, Oppitz PP et al. Solitary fibrous tumor of the sella mimicking pituitary adenoma: an uncommon tumor in a rare location-a case report. EndocrPathol. 2009; 20(1): 56-61.

10. Prévot S, Penna C, Imbert JC et al. Solitary fibrous tumor of the adrenal gland. Mod Pathol. 1996; 9(12): 1170-4.

11. Kuribayashi S, Hatano K, Tsuji H et al. Solitary fibrous tumor mimicking adrenal tumor concomitant with contralateral adrenal pheochromocytoma: A case report of surgical resection after long-term observation. International Journal of Surgery Case Reports 2019; 58: 170-173.

12. Bongiovanni M, Viberti L,GiraudoG et al. Solitary fibrous tumour of the adrenal gland associated with pregnancy. Virchows Arch 2000; 437: 445-449.

13. Yonly DS, Chakroun M, Mokadem S et al. Adrenal solitary fibrous tumor: A case report. Urology case reports 2019; 27: 100919.

14. Gebresellassie HW, Mohammed Y, Kotiso B et al. A giant solitary fibrous tumor of the adrenal gland in a 13-year old: a case report and review of the literature. Journal of Medical Case Reports 2019; 13: 246.

15. Kakihara D, Yoshimitsu K, Eto M et al. MRI of Retroperitoneal Solitary Fibrous Tumor in the Suprarenal Region. AJR 2007; 188 (6): 512-514.

16. Ho YH, Yap WM, Chuah KL. Solitary fibrous tumor of the adrenal gland with unusual immunophenotype: a potential diagnostic problem and a brief review of endocrine organ solitary fibrous tumor. EndocrPathol. 2010; 21(2): 125-129.

17. Park SB, Park YS, Kim JK et al. Solitary Fibrous Tumor of the Genitourinary Tract; AJR 2011; 196: 132-137.

18. Treglia G, Oragano L, Fadda G, et al. A Rare Case of Solitary Fibrous Tumor of the Adrenal Gland Detected by 18F-FDG PET/CT. Clinical Nuclear Medicine 2014, 39(5): 475-477.

19. Toniato A, Merante, Boschin I, Pelizzo MR. A very rare bilateral adrenal tumor. Endocrine. 2014; 45(3): 502-503.

20. Huisman SE, Verlinden I, van Battum P et al., Solitary fibrous tumor of the adrenal gland - its biological behavior and report of a new case. Surgical and Experimental Pathology, 2021; 4(1); $4: 6$.

21. Doyle, L., Vivero, M., Fletcher, C. et al. Nuclear expression of STAT6 distinguishes solitary fibrous tumor from histologic mimics. Mod Pathol 2014; 27, 390-395.

22. Rajeev R, Patel M, Jayakrishnan TT et al. Retroperitoneal solitary fibrous tumor: surgery as first line therapy. Clin Sarcoma Res. 2015; 5: 19. 


\title{
Резиме \\ СОЛИТАРЕН ФИБРОЗЕН ТУМОР НА АДРЕНАЛНАТА ЖЛЕЗДА И ПРЕГЛЕД НА ЛИТЕРАТУРАТА
}

\author{
Мартина Амбарџиева ${ }^{1}$, Скендер Саиди ${ }^{1}$ Рубенс Јовановиќ ${ }^{2}$, \\ Јосиф Јанчулев ${ }^{1}$, Виктор Станков ${ }^{1}$, Александар Трифуновски ${ }^{1}$, Живко Попов $^{3}$ \\ ${ }^{1}$ Универзитетска клиника за урологија, Медицински факултет, Универзитет Св. Кирил и Методиј, \\ Скопје, РС Македонија \\ ${ }^{2}$ Институт за патологија, Медицински факултет, Универзитет Св. Кирил и Методиј, Скопје, РС \\ Македонија \\ ${ }^{3}$ Македонската академија на науките и уметностите, Скопје, РС Македонија
}

Солитарниот фиброзен тумор (СФТ) е редок и сѐ уште контроверзен ентитет. Овој тип тумор во литературата првпат се сретнува како плеврална лезија. Но, во последните декади се сретнува во повеќе екстраторакални места. Како тумор на адренална жлезда, СФТ е сѐ уште редок и невообичаен, па следствено на тоа се направи екстензивно пребарување англиската литература. Тука ви претставуваме случај на СФТ на лева адренална жлезда, споредено со 11 други веќе опишани случаи. Нашиот случај е пациент со СФТ на левата адренална жлезда, проследено со лесни симптоми на абдоминален дискомфорт и хипертензија. Беше извршени клинички преглед, лабораториски и радиолошки иследувања. Пациентот беше хируршки третиран и материјалот беше испратен за хистопатолошка анализа за дефинитивна дијагноза. Редовни контроли беа спроведени во следните две години. Не се забележа рецидив на болеста.

Ги објаснуваме симптомите, дијагнозата и третманот и додатно ги прикажуваме резултатите и наодите пријавени во литературата. Точна дијагноза е неопходна за оптимален менаџмент на пациентите со солитарен фиброзен тумор.

Клучни зборови: солитарен фиброзен тумор, адренална жлезда, адренелектомија 
